\title{
Problems Faced by the Physical Science Teachers in Doing Practical Work in Higher Secondary Schools at Aranthangi Educational District
}

\author{
Dr. S. Malathi ${ }^{1}$, R. Rohini ${ }^{2}$ \\ ${ }^{1}$ Assistant Professor, DDE, Alagappa University, Karaikudi \\ ${ }^{2}$ Research Scholar, Department of Education, Alagappa University, Karaikudi
}

\begin{abstract}
The practical work in science is acknowledged and widely accepted as an important component in the teaching and learning of scientific concepts. The aim of the present paper is to identify the problems that are experienced by physical science teachers in doing practical work. A structured questionnaire was administered to physical science teachers in the Aranthangi Educational District, to identify the problems faced in doing practical work in physical science lessons. Analysis of the data indicated that the main problems that teacher faced in doing practical work in physical science at Higher Secondary Schools were: Absence of adequate time, Unavailability of resources, Large class size, Frequent Assessment pressure in Examinations. If the above problems are overcome, the teachers will be able to do practical work effectively; hence it improves the performance of students in physical science at Higher Secondary level.
\end{abstract}

Keywords: Problems, Physical Science laboratory, Higher Secondary School Teachers

\section{Introduction}

Practical work in science is acknowledged and widely accepted as an important component in the teaching and learning of science concepts. Learning by doing is a cardinal principle of teaching science. Science cannot be taught as a theory subject. Scientific theory is based on the process of inquiry and experimentation. The learning of science without practical work is incomplete. Practical work is an essential component of learning science. The findings in science are put to test in the laboratory. The learning by doing is achieved only through experimentations. Hence we can say that practical work is an utmost necessity and designing practical work in a science laboratory is an effective instructional method of teaching science.

To learn science is to do science. There is no other way of learning science". - Dr.D.S. Kothari

"If I have to live any life again, I would always remain in my laboratory for the greatest joy to my life to accomplish original scientific work". J.B Andre Dumas.

UNESCO mission report on science teaching says, "The guiding principle of science education consists in combining theory and practice".

The National Policy on Education (1986) suggested that science should be taught in an integrated manner up to class $x$ and separately in classes $x i$ and xii. They initiated a new approach to teaching and learning of science. It involves active student participation through experimentation, demonstrations and guided projects by the students. The NCERT working groups made an attempt to maintain close relation between the lab experiments and demonstrations and theory.

\section{Need and Significance of the Study}

The use of laboratory in teaching physical science has become a dogma among physical science educators and teachers. Science teachers do not find convenient to make laboratory work is the centre of their instruction. They usually complain the lack of materials and equipment to carryout practical work. At the same time, it is possible that some of these materials and equipments may be locked up in the school laboratory store without teachers being aware of their existence.

Class size in urban schools is getting larger and this does not usually encourage teachers to use the laboratory to teach physical science. In addition, most of laboratory class rooms are not equipped with work tables that have sinks, a water supply, natural gas and electrical outlets available in sufficient quantity to support a physical science laboratory. There is no enough allocation of funds to provide for such laboratories. There are no approved guidelines for the safe use, maintenance, storage and disposal of laboratory materials. In this aspect, the study has its own importance and the present study assumes significance.

\section{Objectives of the Study}

1) To identify the problems those are faced by physical science teachers in doing practical work in higher secondary schools.

2) To find out the significant difference between the associative factors such as gender, management of school and location of school in relation to problems of laboratory practical's.

3) To provide possible ways of overcoming these problems that teachers encounter. 


\section{International Journal of Science and Research (IJSR) \\ ISSN (Online): 2319-7064}

Index Copernicus Value (2015): 78.96 | Impact Factor (2015): 6.391

\section{Hypotheses of the Study}

1) Physical science teachers faced more problems when doing the science laboratory activities in higher secondary schools.

2) There exist a significant difference between the associative factors such as gender, management of the school and location of the school in relation to the problems faced by the physical science teachers when doing practical work.

\section{Methodology}

\section{Research Method}

This study adopted a descriptive survey method. In this study the data collected from the physical science teachers with the view of ascertaining problems that are faced in doing practical work in physical science at higher secondary schools in Aranthangi Educational District.

\section{Research Tool}

The investigator herself constructed a research tool on identification of problems faced by the physical science teachers when doing laboratory practical work at Higher Secondary schools. In this study the investigator used questionnaire to collect data from the respondents. The questionnaire consisting of two sections. Section 'A' was used to collect the demographic characteristics of the respondents, section B consisted twenty items on a 3-point likert type responses rating scale: Agree (A), Disagree(D) and Uncertain(U).

\section{Sampling and Sample Size}

The sampling procedure was used to collect the data is simple random sampling technique. The researchers have chosen 15 Higher Secondary Schools and the sample for the study consisted of 30 Higher Secondary physical science teachers from the Aranthangi Educational District.

\section{Data Analysis}

The investigator used statistical technique such as percentage analysis to analyze the data collected for this study.

\section{Results and Discussion}

Table 1: Summarizes the results of the survey conducted to determine the problems that are physical science teachers faced in doing practical work in Higher Secondary schools.

Table 1: Summary of Results

\begin{tabular}{|l|l|c|c|c|}
\hline Sl.No & Items & Agree $\%$ & Disagree $\%$ & Uncertain \% \\
\hline 1 & Absence of adequate time & 100 & 0 & 0 \\
\hline 2 & Unavailability of Resources & 90 & 10 & 0 \\
\hline 3 & Absence of proper atmosphere and congenial place & 80 & 20 & 0 \\
\hline 4 & Large class size & 90 & 10 & 0 \\
\hline 5 & Learners indiscipline & 70 & 20 & 10 \\
\hline 6 & No laboratory facilities & 50 & 30 & 20 \\
\hline 7 & Inflexible curriculum & 60 & 40 & 0 \\
\hline 8 & Absence of technical support & 80 & 20 & 0 \\
\hline 9 & Frequent assessment pressure in examinations & 90 & 10 & 0 \\
\hline 10 & Lack of support from management & 10 & 50 & 40 \\
\hline 11 & Absence of proper ventilation & 20 & 40 & 40 \\
\hline 12 & Teachers inexperience & 60 & 20 & 20 \\
\hline 13 & Absence of first aid facilities & 40 & 30 & 30 \\
\hline 14 & Absence of lab Assistant & 80 & 20 & 0 \\
\hline 15 & Budget constraints & 70 & 30 & 0 \\
\hline 16 & Absence of teachers motivation & 20 & 50 & 30 \\
\hline 17 & Lack of professional development trainings & 60 & 20 & 20 \\
\hline 18 & Theft of equipments & 50 & 30 & 20 \\
\hline 19 & In adequate text books & 80 & 10 & 10 \\
\hline 20 & Absence of organization and planning activities & 60 & 40 & 0 \\
\hline
\end{tabular}

The above table reveals the percentage scores of problems faced by the physical science teachers when doing practical work at Higher Secondary level.

The results of this research indicate that absence of adequate time are the main problem that physical science teachers faced in conducting practical work, here all the 30 respondents agreed the absence of adequate time.

Unavailability of resources, Large class size, Frequent assessment pressure in examinations are also significant problems (when $90 \%$ of the respondent agreed with these statements). Unavailability of resources is a major issue for many Higher Secondary schools, especially in rural areas as they have no standard equipment for physical science practical work. Large class size also another important problems because the teachers don't have a time to give individual care. Assessment of learners is an integral part of the teaching and learning process, compulsory assessment tasks erode into teaching time. Teachers are thus, preparing their students only in theoretical aspects of the curriculum for assessment exercises, this leads to the poor performance in physical science lab activities. 3

Absence of proper atmosphere and congenial place, Absence of technical support, absence of the lab assistant are the significant problems, where $80 \%$ of the respondents agreed these statements.

This study reveals that $70 \%$ of the respondents were agreed the learners indiscipline in the practical classroom and also

\section{Volume 6 Issue 1, January 2017




\section{International Journal of Science and Research (IJSR) \\ ISSN (Online): 2319-7064}

Index Copernicus Value (2015): 78.96 | Impact Factor (2015): 6.391

$70 \%$ of respondents were agreed budget constraints from their managements.

Inflexible curriculum, Teachers inexperience, Lack of professional development trainings, Absence of organization and planning activities are the significant problems, where $60 \%$ of the respondents agreed these statements.

No laboratory facilities, Theft of equipments are the significant problems $50 \%$ of the physical science teachers agreed these statements. The remaining problems faced by the physical science teachers are below average.

Table 2: Distribution of percentage scores of laboratory problems faced by the Higher Secondary physical science teachers in different management of the school

\begin{tabular}{|c|l|c|}
\hline S. No & \multicolumn{1}{|c|}{ Categories } & $\begin{array}{c}\text { Percentage scores of } \\
\text { problems (\%) }\end{array}$ \\
\hline 1 & Government school & $80.53 \%$ \\
\hline 2 & Government Aided school & $60.56 \%$ \\
\hline 3 & Private school & $72.31 \%$ \\
\hline
\end{tabular}

While comparing the percentage scores of different management of the schools, the percentage scores of problems faced by government schools are $80.53 \%$, the percentage scores of problems faced by the government Aided schools are $60.56 \%$ and the percentage scores of problems faced by the private schools are $72.31 \%$.

Finding: The above table revealed that the levels of problems faced by the government school physical science teachers are at a greater extent than Government Aided schools and private schools. In most of the Government school physical science laboratory classrooms are not equipped with adequate facilities, laboratory instruments, congenial place, absence of fund allocation, assessment pressure in examinations, etc., are the main problems faced by the government school physical science teachers.

Table 3: Distribution of percentage scores of laboratory problems faced by the Higher Secondary physical science teachers in different location of the school

\begin{tabular}{|c|c|c|}
\hline S. No & Categories & Percentage scores of problems (\%) \\
\hline 1 & Rural & $78.33 \%$ \\
\hline 2 & Urban & $63.14 \%$ \\
\hline
\end{tabular}

While comparing the percentage scores of different location of the school, the percentage scores of the problems faced by the Rural schools are $78.33 \%$ and the percentage scores of problems faced by the Urban schools are $63.14 \%$.

Findings: The above table revealed that the level of problems faced by the Rural school physical science teachers are at a greater extent than the Urban schools. In many rural schools are not equipped with adequate facilities. There is no separate physical science laboratory facility in many rural schools. Absences of proper atmosphere in the laboratory are the main problems faced by the rural school Higher Secondary physical science teachers than the urban school physical science teachers.

\section{Recommendations}

As a Result of this research the following recommendations are made, so that the problems in doing practical may overcome:

- The time allocated for the teaching of physical science in the higher secondary schools needs to be increased, so that teachers can get themselves as well their students involved in practical work.

- Teachers need to form support groups to develop skills in doing practical work.

- In - Service Courses in doing effective practical work should be conducted by subject advisers and experienced physical science teachers.

- Teachers need to request from the school management, that a budget be made available for the purchase of necessary science equipment and resources. The school can also engage in fund raising activities for the purpose of purchasing of equipment needed to conduct practical work.

\section{Conclusions}

Practical work forms an integral part of teaching and learning in physical science. If physical science teachers experience problems in doing practical work and these problems are not overcome, they will be discouraged from doing practical work. Learners will not be able to acquire valuable skills that are required, especially in the work place. It practical work is added as an integral part of the teaching and learning process, scientific concepts, skills and values will surely be acquired by learners and this will enhance their performance in science.

\section{References}

[1] Abrahams A 2009 Does practical work really motivate? A study of the affective value of practical work in secondary school science. International Journal of science Education, 31(17) 2335-2353.

[2] Donnelly D. O'Reily J. McGarr O 2013 Enhancing the student experiment experience: Visible scientific inquiry through a virtual chemistry laboratory. Research in Science Education, 43: 1571-1592.

[3] Heeral PJH, Bayaga A 2011. Pre-service teachers' experiences of teaching practice Case study of a South African university. Journal of Sciences, 28.2.

[4] P.J.H. Heeralal 2014. Barriers Experienced by Natural Science Teachers in doing Practical work in Primay schools in Gauteng. University of South Africa, College of Education, Department of Science and Technolgoy.

[5] Kibrige1, Osodo J. Mgiba AN 2014. Exploring grade 7 teachers' perceptions regarding practical work in Limpopo, south Africa. Mediterranean Journal of Social Sciences, 5(4): 399-485.

[6] Lunetta VN, Hofstein A. Clough MP 2007 Teaching and learning in the school science laboratory. An analysis of research, theory, and practice In: SK Abell, NG Lederman (Eds) : Handbook of Research on Science Education Mahwah, NJ: Lawrence Erlbaum Associates, pp.393-431 